Feng, Y., Hassan, A., \& Elamer, A.A., (2020) 'Corporate governance, ownership structure and capital structure: Evidence from Chinese real estate listed companies', International Journal of Accounting \& Information Management, Forthcoming, (Accepted 9 June 2020). https://doi.org/10.1108/IJAIM-04$\underline{\text { 2020-0042 }}$

\title{
Corporate governance, ownership structure and capital structure: Evidence from Chinese real estate listed companies
}

\section{Yi Feng}

Adam Smith Business School, University of Glasgow, Glasgow, UK

E-mail: 353374893@qqq.com

\begin{abstract}
Abeer Hassan
Accounting, Finance and Law Unit, Institute for Accounting and Financial Markets, School of Business and Enterprise, University of the West of Scotland, Paisley, PA1 2BE, UK Email: Abeer.Hassan@uws.ac.uk
\end{abstract}

\begin{abstract}
Ahmed A. Elamer *
Brunel Business School, Brunel University London, Kingston Lane, Uxbridge, London, UB8 3PH UK; and

Department of Accounting, Faculty of Commerce, Mansoura University, Mansoura, Egypt Email: ahmed.a.elamer@gmail.com

*Corresponding author
\end{abstract}

*Corresponding author: Brunel Business School, Brunel University London, Kingston Lane, London UB8 3PH, UK, E-mail: ahmed.elamer@brunel.ac.uk or/and ahmed.a.elamer@gmail.com. 


\title{
Corporate governance, ownership structure and capital structure: Evidence from Chinese real estate listed companies
}

\begin{abstract}
Purpose - This paper seeks to contribute to the existing capital structure and board structure literature by examining the relationship among corporate governance, ownership structure and capital structure.
\end{abstract}

Design/methodology/approach - The paper employs a panel data of 595 firm-year observations from a unique and comprehensive dataset of 119 Chinese real estate listed firms from 2014 to 2018. It uses fixed effect and random effect regression analysis techniques to examine the hypotheses.

Findings - The results show that the board size, ownership concentration and firm size have positive influences on capital structure. State ownership and firm profitability have inverse influences on capital structure.

Research limitations/implications - The findings suggest that better-governed companies in the real estate sector tend to have better capital structure. These findings highlight the unique Chinese context and also offer regulators a strong incentive to pursue corporate governance reforms formally and jointly with ownership structure. Lastly, the results suggest investors the chance to shape detailed expectations about capital structure behaviour in China. Future research could investigate capital structure using different arrangement, conducting face-toface meetings with the firm's directors and shareholders.

Practical implications- The findings offer support to corporate managers and investors in forming or /and expecting an optimal capital structure, and to policymakers and regulators for ratifying laws and developing institutional support to improve the effectiveness of corporate governance mechanisms.

Originality / value - This paper extends, as well as contributes to the current capital structure and corporate governance literature, by proposing new evidence on the effect of board structure and ownership structure on capital structure. The results will help policymakers in different countries in estimating the sufficiency of the available corporate governance reforms to improve capital structure management.

Keywords: Corporate governance; agency theory; board structure; ownership structure; capital structure 


\section{Introduction}

Capital structure, as a critical area affecting the overall operating level of corporates, has been a focus in the field of corporate finance and accounting (Abor and Bikpie, 2007; Huang, 2019; Neves et al., 2020). One of the motivations of capital structure management is to reduce capital cost and maximize the shareholders' interests (Danso et al., 2019; Uwuigbe, 2014). Corporate governance, on the other hand, is a mechanism to maximize shareholder value through organizational' management, which has always been related to agency problems (Adel et al., 2019; AlHares, 2020; AlHares et al., 2020; Gerged \& Elheddad, 2020; Gerged \& Agwili, 2020; Gerged et al., 2018; Ullah et al., 2019; Uwuigbe, 2014). Corporate governance seems to affect the capital structure and plays an important role in corporate financing decisions (Haque et al., 2011). Firms can achieve their corporate objectives, protect shareholders rights and meet legal compliances through a strong corporate governance structure (Alshbili \& Elamer, 2019; Granado-Peir and López-Gracia, 2017; Elamer et al., 2020a, b; Elmagrhi et al., 2018). Specifically, corporate governance aims to ensure that opportunistic behaviour does not occur, by mitigating agency problems that could involve insiders (manager) and outsiders (e.g., shareholders, debt holders, investors etc.) (Allam et al., 2017; Eldaly, 2012; Eldaly \& AbdelKader, 2018; Kim et al., 2016). Moreover, it helps the creation of particular skill required in strategic decisions (incentive to firm-specific investment) and limit problems of asymmetric information (Hassan et al., 2019, 2020; Muttakin et al., 2020; Yu \& Wang, 2018).

Despite ample of evidence on the determinants of capital structure, extant research (Abor and Bikpie, 2007; Huang, 2019; Neves et al., 2020) argues that the capital structure decision is a puzzle for accounting and finance researchers. This puzzle is because of different capital structure theories and/or different quantitative regression models lead to inconclusive results (Hussainey and Aljifri, 2012). Thus, this study investigates how corporate governance mechanisms may improve capital structure management due to three motives. Firstly, according to agency theory, agency cost plays an important role in both capital structure and corporate governance decisions related to financial policy. (Granado-Peir and López-Gracia, 2017; Boateng et al., 2017; Chow et al., 2018; Li \& Song, 2018; Long \& Huang, 2020; Yu \& Wang, 2018). Second, while there are many studies focused solely on corporate structure (Brailsford et al., 2002) or corporate governance (Abor and Biekpe, 2005; Ganiyu and Abiodun, 2012; Ali et al., 2014), few studies covered the relationship between them (Butt, and Hasan, 2009). Our paper considers the influences of both board structure (board size, board 
independence and CEO duality) and ownership structure (ownership concentration, management ownership and state ownership) on capital structure. Third, the results of the few studies that covered the relationship between corporate governance and capital structure are inconsistent.

On the one hand, a strand of the literature suggests a negative relation between corporate governance mechanisms and capital structure. For instance, Arping and Sautner (2010) find a significant decrease in debt ratio due to the change in corporate governance codes in Netherland. They suggest that effective governance leads to lower level of debt. Jiraporn et al. (2012) show that when managers are more embedded with poor governance, firms be likely to have considerably more debt. They conclude that firms are using capital structure as a substitute for corporate governance in their effort to attenuate agency problems. On the other hand, another strand of literature found a positive relation between corporate governance mechanisms and capital structure. For example, Ghosh et al. (2011) find that self-serving managers favour of use less debt. They suggest that self-interested managers use lower debt to attenuate liquidity risk, and continue their capacity to further increase their reputations and compensation. Using a sample of UK firms, Sun et al. (2015) found a positive association between institutional ownership and capital structure. Generally speaking, literature on corporate governance suggests that corporate governance and ownership structure play a crucial role in monitoring and guiding the managers, and reduce conflict of interests in decision making. Besides, effective governance is observed to have a significant influence on the firms' capital structure choices.

Our paper examines the above relationship in China. Most research on China just focus on the ownership structure (Xu and Wang, 1999; Tian, 2001; Wang et al., 2019; Ruan et al., 2011), few studies on the board structure (Wen et al., 2002) and none focused on the above relationship. In addition, corporate governance in China has some unique characteristics: 1) Due to the differences in social systems between China and Western countries, the establishment and implementation of western corporate governance practices adopted by Chinese regulators are still controversial (Rajagopalan and Zhang, 2008), 2) Compared with Western countries, Chinese legal protection of shareholders is weak and ownership is highly concentrated (Yuan et al., 2009). Therefore, the unique nature of corporate governance in china encouraged us to measure the relationship between capital structure and board structure. We focus on the real estate industry for the following reasons: 1) No research studies have conducted on the real 
estate industry, in general, and in China in particular. 2) The development of the real estate industry is very important to promote Chinese economic development and economic restructuring (Chen et al., 2009). Additionally, it is worth noting that Chinese governments rely more on real estate industry income (Xu et al., 2016), which also implies that the state ownership in the real estate industry may affect corporate governance

Therefore, our study contributes to the extant literature in many ways. To the best of our knowledge, this paper focuses on enterprises in Chinese Real Estate industry, which has not been covered before by other scholars. Also, our paper examines both board and ownership structures on capital structure. Our results conclude that ownership concentration, state ownership, company size and company profitability are related to capital structure. Our results support the previous studies (Wen et al., 2002; Sharma and Kumar, 2011; Mande et al., 2012) and provide some practical suggestion for corporate operation. Our findings also may be beneficial and appropriate to these countries as well. Particularly, managers should be aware of the benefits of the application of strong corporate governance mechanisms while embracing international corporate governance codes. Furthermore, investors (managers) should consider both capital structure and institutional when they take their investment (financing) decisions. Finally, our results may support policymakers and regulators in pursuing the initiatives to implement effective corporate governance mechanisms through improving the regulatory and enforcement corporate governance framework.

The rest of the paper is structured as follows. Section 2 is a theoretical framework and Chinese context. Section 3 presents literature review and hypotheses development. Section 4 introduces the research methods, measurement of various variables, data sources and regression models. This followed by section 5 to present our results and discussion. Finally, section 6 to provide a conclusion of the paper.

\section{Theoretical framework and Chinese Context}

\subsection{Chinese context:}

The centralized ownership, coupled with the lack of external governance mechanism in China, may lead to the conflict of financing decisions between major shareholders and minor shareholders (Boateng and Huang, 2017). For example, Faccio et al. (2010) argue that 
corporate leverage would enable large shareholders to deploy borrowing resources for their own interests at the expense of small shareholders without fully considering the cost of bankruptcy. On the other hand, large shareholders can also alleviate agency problems due to the motivation of supervisory management (Shleifer and Vishny, 1997). In relation to China, according to the "Code of Corporate Governance for Listed Companies" issued by China Securities Regulatory Commission (CSRC) and State Economic and Trade Commission in 2002, the board of directors is defined as a decision-making control unit, and the board of supervisors is defined as a supervisory unit (Guo et al., 2013). According to this code, the board size of each listed company in China should be 5-19. This code requires that the independent directors should not be less than one third, and the independent ownership should not exceed one percent and they should not become one of the top ten shareholders. The leadership structure is not limited, which means that companies can choose the duality structure or non-duality structure freely. In China, both the board of directors and the board of supervisors report to the shareholders' meeting without a hierarchical relationship, which is different from Western countries, like Germany (Schipani and Liu, 2002). According to the Code, at least three supervisors are required for large listed companies, and directors and senior managers are not allowed to act as supervisors. Supervisors can attend board meetings without voting rights, and they have poor observation ability (Qian and $\mathrm{Wu}, 2003$ ). Based on this, this paper just focuses on the board of directors rather than the board of supervisors.

In addition, due to the differences in history, culture and social systems between China and Western countries, China also has a distinct ownership structure. Before the 1980s, China was oriented by the planned economy; most large enterprises were owned and controlled by the government (Qi et al., 2000). The managers were appointed directly by the government, and they were closely related to the owners of state-owned enterprises (Kang and Ausloos, 2017). Since 1978, when China began its reform and opening, state-owned enterprises started to reform and private enterprises have been rising. Shanghai Stock Exchange and Shenzhen Stock Exchange were established in 1990 and 1991, respectively (ibid.). Chinese economic system has gradually changed from a planned economy to a market economy, and managers have become more independent and have a greater influence on companies, then the agency problem of the separation of control and ownership has gradually emerged. According to the Chinese Company Law, stocks are designated to be owned by the state, legal person or individual. Stateowned shares refer to shares held by governments and relevant departments; corporate shares are held by enterprises; individual shares are held by individuals; and the control right of listed 
companies in China is relatively centralized and dominated by Chinese governance structure (Guo et al., 2013).

\subsection{Theoretical framework}

Agency theory is widely used to demonstrate the relationship between corporate governance and capital structure (Fama and Miller, 1972; Jensen and Mecklin, 1976). Based on agency theory, the divorce of ownership and control, the conflict of interest between the principal and the agent results in agency cost, which affects the decision-making of capital structure (Agyei and Owusu, 2014). The common agency conflict is the conflict of interest between management \& directors (agent) and shareholders (principals). The agents should take the interests of the principals for decision-making. However, in reality, the management may sacrifice the interests of the shareholders out of opportunism, and the consequences suffered by shareholders are defined as agency costs (Jiraporn et al., 2012).

Corporate debt policy is an important way to alleviate agency conflict between shareholders and managers because debt financing can solve agency problems by reducing cash flow and increasing the possibility of bankruptcy risk (Haque et al., 2011; Danso et al., 2019; Hussainey \& Aljifri, 2012; Muttakin et al., 2020). In addition, another conflict of interest is between controlling shareholders and minority shareholders. Major shareholders may deprive minority shareholders of their interests, resulting in huge agency problems. Based on the above discussion, we adopt agency theory because the agency problem (separation of ownership and control i.e. corporate governance) will affect the capital structure decision. Therefore, we are investigating whether corporate governance affects the capital structure decision.

\section{Literature Review and hypotheses development}

\subsection{Board structure and capital structure}

Board size: There is evidence that the board size has a direct relationship with the capital structure based on existing literature. On the one hand, the two have a positive relationship that is because, first, when the board size is large, the decision-making efficiency of the board may decline, which makes it difficult for board members to reach a consensus in the decisionmaking process, leading to high leverage (Abor and Biekpe, 2007). At the same time, larger 
board size means more serious agency problems caused by corporate control and ownership, and based on agency theory, this means more debt capital is needed to alleviate agency problems. Second, creditors tend to believe that companies with larger boards implement more effective supervision and as a result, the cost of debt goes down (Bokpin and Arko 2009; Khan and Wasim, 2016; Rehman et al., 2010). On the other hand, it is believed that the larger the board size, the lower the debt ratio (Berger et al., 1997; Abor and Biekpe, 2007; Vakilifard et al., 2011). Berger et al. (2007) and Vakilifard et al. (2011) find that board size is negatively associated with leverage, implying that large boards are related to coordination, communication and decision-making issues and hence, ineffective in avoiding entrenched CEOs from pursuing lower leverage ratio. Another explanation is for companies with a large board, the management will face more supervision pressure, thus forcing them to reduce leverage ratio and improve corporate performance (ibid.). Given the above discussion, we propose testing the

\section{Hypothesis 1. Board size is related to capital structure.}

Board independence. As for board independence, on the one hand, Pfeffer and Salancik (2003) believe that the higher the independence of the board, the higher the leverage. They believe that independent directors can help companies gain recognition and trust from outside investors, thus reducing the uncertainty of companies and improving the financing ability of companies. Because independent directors are generally considered to have more professional knowledge and are mostly fretful about their reputations and social prestige, they are independent of management (Ali et al., 2014; Boroujeni et al., 2013; Khan and Wasim, 2016). However, agency theory holds that independent directors strengthen the supervision of management, thus reducing the debt ratio (Boateng et al., 2017). Wen et al. (2002) think that, when a board is controlled by independent directors, senior managers are often faced with stricter supervision, which leads managers to adopt lower leverage to avoid pressures related to commitments to surrender large amounts of cash. In addition, Lin et al. (1998) and Feinerman (2017) argue that stricter supervision forces managers to use less debt to avoid excessive risk, reduce uncertainty, and debt-related disciplinary effects. Nevertheless, Bokpin and Arko (2009) found no statistical correlation between them. Given the above discussion, we propose testing the following hypothesis: 
Hypothesis 2. Board independence is related to capital structure.

\section{CEO duality.}

Means there is no separation between ownership and control (Butt and Hasan, 2009). On the one hand, Uwuigbe (2014), Kang and Ausloos, (2017) think that there is a positive correlation between CEO duality and capital structure. They believe that the CEO duality in a company generally reduces the agency cost of separation of ownership and control, thus alleviating the problem of information asymmetry.

On the other hand, Fosberg (2004) and Abor (2007) argue that when the CEO and the Chairman are not the same person, the capital structure in a company is most likely to be the optimal capital structure, which means that the debt ratio will be higher. According to agency theory, when there is no CEO duality, it means that the agency problem is generated, and more debt is needed to alleviate the agency problem. Abor (2007) also believes that CEO duality is negatively correlated with leverage ratio, which means that when corporate control and decision-making power are separated, the leverage ratio is higher. However, Bodaghi and Ahmadpour (2010) concluded that CEO duality has no significant impact on corporate financing behaviour based on research from Iran. At the same time, Kang and Ausloos (2017) also found that there was no significant correlation between CEO duality and leverage. However, Kang and Ausloos (2017) concluded that CEO duality has no significant impact on corporate financing behavior

\section{Hypothesis 3. CEO duality is related to capital structure.}

\subsection{Ownership structure and capital structure}

Ownership concentration. As for the ownership concentration, it is positively correlated with capital structure. Due to the separation of ownership and control, the agency problems exist between shareholders and managers (Ali et al., 2014). Also, ownership concentration can help to alleviate the agency problem because large shareholders have the ability to influence management decisions and actions more than ordinary shareholders. The major shareholders have incentives, as maintaining their authority and information advantage (Haque et al., 2011), to monitor and influence managers' decisions to protect their investment (Liu et al., 2011). 
According to agency theory, major shareholders may increase debt to deprive minority shareholders of power. According to Qi et al. (2000) and Fosberg (2004), major shareholders prefer to force the management to use more debt to improve enterprise performance. In addition, the expropriation effect of major shareholders on minority shareholders has become one main problem affecting corporate governance (Bebchuk and Weisbach, 2010), and the debt's increasing is one effective tool to expropriate minority shareholders (Mande et al., 2012). On the other hand, some studies suggest that higher ownership concentration will lead to a decline in the proportion of debt financing. According to Lin et al. (2011), excessive control of major shareholders contributes to potential threats and other moral hazard activities, which will increase the monitoring costs and credit risks faced by banks, and then, in turn, raises the cost of debt for borrowers. In China, although the Chinese expropriation effect is more serious than that of western countries, listed companies in China, especially state-owned enterprises, have built-in equity financing incentive mechanisms (Zou and Xiao, 2006), so the major shareholder shareholding of state-owned enterprises may be negatively correlated with corporate leverage. Given the above argument, we propose testing the following hypothesis:

\section{Hypothesis 4. Ownership concentration is related to capital structure.}

State ownership. At present, there is little research on the relationship between the proportion of state-owned shares and capital structure. State ownership is positively correlated with capital structure (Tian, 2001), because raising funds by selling shares to private capital may threaten the dominant position of governments (Xu and Wang, 1999). When the proportion of state-owned shares in a company is high, especially the firms are state-owned companies, the government will support the development of these firms, thereby these companies can get more debt from outside creditors (ibid.). Zou and Xiao (2006) believe those agency problems are usually serious in enterprises with higher state-owned components; thus they need to make full use of debt to supervise management. In contrast, Saad (2010) found a negative correlation between state-owned ownership and the probability of financial distress, which indicates that the higher the state-owned composition, the lower the bankruptcy cost, thus the lower the financing cost, which may increase the proportion of debt financing. In China, Liu et al. (2011) found that state ownership is directly positively related to the debt ratio. This is because the Chinese government is usually the owner of major banks, so the Chinese government tends to exert pressure on the banking system to make them lend more to state-owned enterprises (Li et al., 2009). Also, debt can be employed by state agents to pursue their own economic and/or 
social aims causing damage to minority shareholders. Given the above analysis, we propose testing the following hypothesis:

Hypothesis 5. State-owned ownership is related to capital structure.

Management ownership. The previous studies of Mehran (1992) and Short et al. (2002) found that corporate ownership encourages managers to increase corporate debt capital, suggesting that managers whose financial enticements are more likely aligned with outsiders' wealth will pursue more debt to expand the value of the firm or/and raise their own voting power and decrease the likelihood of takeover. On the other hand, according to agency theory (Jensen, 1993), managers are more inclined to adopt sub-optimal leverage levels to avoid the constraint effect of debt. Self-interested managers will use free cash flow more freely, which may lead to the phenomenon of high investment costs (Granado-Peiró and López-Gracia, 2017), and Berger et al. (1997) also believed that negative correlation. In addition, some studies suggest that there is a non-linear relationship between management shareholding ratio and capital structure. Based on Ruan et al. (2011), who studied Chinese private listed companies, their research results show that when the proportion of management remains below $18 \%$ or more than $46 \%$, there is a negative correlation relationship between management ownership and leverage, however, when management ownership between $18 \%$ and $46 \%$, there is a positive correlation. Brailsford et al. (2002) also found non-linear relationship. Given the above debate, we propose testing the following hypothesis:

Hypothesis 6. Management ownership is related to capital structure.

\section{Methodology}

Following the stream of prior studies (Kang and Ausloos, 2017; Boateng et al., 2017; Liu et al., 2011; Jiraporn et al., 2012; Saad, 2010; Uwuigbe, 2014), we measure corporate governance by the board size, CEO duality, board independence, ownership concentration, state ownership and management ownership. Capital structure is measured by the total debt ratio, short-term debt ratio and long-term debt ratio Mirza et al., 2017). Control variables are measured by firm size, profitability, asset tangibility and growth (Bhabra et al., 2008; Chang et al., 2014; Huang et al., 2016; Santos et al., 2014). 


\subsection{Research variables}

Dependent variables: Based on previous research, this paper employs three distinct proxies to measure a firm's capital structure: total debt ratio (TD), short-term debt ratio (STD) and long-term debt ratio (LTD) (Mirza et al., 2017). The most widely used capital structure proxy is the total debt ratio, defined as the ratio of total debt to total assets (TD) (Kumar, 2005; Haque et al., 2011). The short-term debt ratio is measured by short-term debt divided by total assets (STD) and the long-term debt ratio is calculated by long-term debt divided by total assets (LTD) (Dasilas and Papasyriopoulos, 2015) (see table 1 for research variables).

Independent variables: The first independent variable is board size, which is measured as the nature logarithm of the total number of board members (BOD) (Kang and Ausloos, 2017). The second one is the board independence, which is represented by the percentage of the number of independent directors divided by the total number of the board (IDR) (Boateng et al., 2017). Based on previous studies (Saad, 2010; Uwuigbe, 2014), CEO duality is designed as a dummy variable. If the CEO and the chairman are the same person, the value of this variable is 1 , and if the CEO and the chairman are not the same person, this value will be 0 (DUA). The fourth variable is ownership concentration, according to Boateng et al., (2017), who represent the ownership concentration by the shareholding ratio of the first few major shareholders, this paper represents the shareholding ratio of the first major shareholder (OC). In the robustness test, this paper will use the top five shareholder shareholding ratios to represent ownership concentration $\left(\mathrm{OC}^{1}\right)$. The fifth variable is state ownership, defined as the shareholding ratio of the state (STATE), according to Liu et al. (2011). The six variable is management ownership, which is defined as the shareholding ratio of management (MGT) Jiraporn et al., (2012) (see table 1 for research variables). 
Control variables. In order to reduce the influence of confounding variables on the observational study, this paper adopts four variables representing the characteristics of companies as control variables. Firm size. Trade-off theory holds that debt ratio and firm size are positively correlated. Fama and French (2002) argue that large firms have a higher level of diversification and a more stable income level, so they have lower bankruptcy costs, which enables them to take on more debt. In addition, large companies pay more attention to information asymmetry, so the public has more confidence in the information quality of large companies, which makes it easier for large companies to borrow debt (Palacín-Sánchez et al. 2013). On the other hand, pecking order theory holds that firm size is negatively correlated with the leverage ratio. Because large companies usually have a relatively high level of operational capability and a good record of performance, they can accumulate more internal resources and have a wider range of sources of financing, thus reducing their dependence on debt (Sogorb-Mira, 2005). Based on Haque et al. (2011), the book value of total assets is appropriate to represent the size of firms. And in order to conform to the normal distribution, this paper applies the logarithm of total assets (SIZE) to represent the firm size (Huang et al., 2016). In the robustness test, this paper will use the logarithm of total sales ( $\mathrm{SIZE}^{1}$ ) to represent firm size (Kang and Ausloos, 2017). This paper predicts that firm size can have an impact on capital structure. Profitability. The second control variable is firm profitability. According to agency theory, profitability is positively correlated with capital structure. Enterprises with higher profitability can have more free cash (Jensen, 1986), thus managers are motivated to use free cash to serve their own interests at the expense of shareholders, and debt can be used to limit such behaviour. The trade-off theory agrees with the agency theory, trade-off theory holds that enterprises with high profitability will increase their debt level out of the consideration of tax liability (Mac and Bhaird, 2010). However, pecking order theory thinks that profitability is negatively correlated with the level of the debt ratio, because the high level of profitability makes the cash flow of the enterprise sufficient, which reduces the possibility of debt operation. Ching et al. (2011) have proved this negative correlation in their investigations. Return on assets (ROA) is the most commonly used index to measure the profitability of firms. Therefore, ROA is regarded as the representative of profitability in this paper, it is calculated as EBIT divided by the book value of the total assets (PROFIT) (Bhabra et al., 2008). In the robustness test, the return on equity (PROFIT ${ }^{1}$ ) was used to represent profitability (Dasilas and Papasyriopoulos, 2015). This paper predicts that profitability can have an impact on capital structure. Tangibility. On the one hand, some studies suggest that the asset tangibility of a firm is significantly positively correlated with its debt level (Korteweg, 2010). Because when a 
business applies for a loan, tangible assets can be used as collateral, increasing the probability of success of the loan. In addition, collateral can reduce credit risk and bankruptcy costs (Dasilas and Papasyriopoulos, 2015). On the other hand, some studies suggest that there is a significant negative correlation between tangibility and short-term debt ratio (Ortiz-Molina and Penas, 2008). Growth. Pecking order theory holds that there is a positive correlation between firm growth and leverage. As a growing company, internal resources cannot meet the capital needs for its development, and it is more inclined to seek external resources (Mateev et al., 2013).

\section{Insert table (1) around here}

\subsection{Regression analysis}

We follow the stream of the prior empirical studies (e.g., Mirza et al., 2017), and run multiple regression model to estimate the possible relationship between corporate governance and the capital structure of Chinese real estate industry. The model is below:

$$
\begin{aligned}
& \text { Capital Structure }\left(\text { TD }_{i, t} ; \operatorname{STD}_{i, t} ; \operatorname{LTD}_{i, t}\right) \\
& \qquad \begin{aligned}
= & \alpha_{0}+\beta_{1} B O D_{i, t}+\beta_{2} I D R_{i, t}+\beta_{3} D U A_{i, t}+\beta_{4} O C_{i, t}+\beta_{5} S T A T E_{i, t} \\
& +\beta_{6} M G T_{i, t}+\beta_{7} \operatorname{SIZE}_{i, t}+\beta_{8} \text { PROFIT }_{i, t}+\beta_{9} T A N G_{i, t}+\beta_{10} G R O W T H_{i, t} \\
& +\varepsilon_{i, t}
\end{aligned}
\end{aligned}
$$

\subsection{Sample and Data}

To measure the relationship between corporate governance and capital structure of the listed real estate companies in mainland China, we used the industry classification of the industry guidance issued by the China Securities Regulatory Commission (CSRC) in 2012. According to this classification, there are 144 listed real estate companies in Chinese securities market. We removed 25 companies due to missing information; companies listed less than 5 years, and companies with poor/abnormal performance. As a result, 119 listed real estate companies are used. The data sources of this paper mainly come from the China Securities Market and Accounting Research Database (CSMAR), which mainly provides financial statements, stocks, corporate governance and other information of Chinese listed companies, with high data reliability and comparability, and it is the most widely used financial database in China ( $\mathrm{Su}$, 2015). We download the data of 119 listed real estate companies from 2014 to 2018 from 
CSMAR, which is the latest available data to get 595 observation, in total, over 5 years.

\section{Empirical results}

\subsection{Descriptive statistics analysis}

Table 2 shows the descriptive statistics of capital structure, corporate governance and corporate characteristics of 119 Chinese real estate listed companies from 2014 to 2018. Just as Table 2 shows, the average total debt ratio in the real estate industry is nearly $65 \%$, which is higher than that in European countries (47\%) (Morri and Cristanziani, 2009). In addition, this average leverage is even twice that of real estate listed companies in North America, Asia and Europe, whose total debt ratio is close to $30 \%$ (Ali et al., 2014). Besides, according to Wang et al. (2019), the average total debt ratio of Chinese-listed as a whole is around $45 \%$. These empirical results show that the average leverage ratio of real estate industry in China is higher than that of the developed countries and the whole industry in China. These pieces of evidence show that the Chinese real estate industry prefers debt financing to equity financing. One explanation may be that the risk of the financial crisis of Chinese banks is relatively low and companies are willing to use debt because the return of debt exceeds the cost of debt (Li et al., 2009). The short-term debt ratio is approximately $43 \%$, which is nearly twice as the long-term debt ratio $(22 \%)$, which implies that real estate prefers to the short-term debt. This phenomenon is the same as the entire industry in China, whose average short-term debt (36\%) is also higher than long-term debt (8\%) (Wang et al., 2019). This phenomenon may be caused by the serious violation of loan contracts by some Chinese enterprises (Zou and Adams, 2008), so banks will restrict the issuance of long-term loans. As for corporate governance, the mean of board size demonstrates that the most of the 119 real estate Chinese listed firm usually have 9 board members, which is a suitable board size for a company based on Lin et al. (2006), who thinks the best board size is between seven and nine. In addition, the standard deviation of board size is relatively large, indicating that the board size fluctuates greatly in this industry. The average value of board independence is around 0.38 , indicating that $38 \%$ of real estate industry companies in the similar board independence situation. And the mean figures of CEO duality are around 0.17 , which shows that CEO duality is not a common phenomenon. As for the ownership concentration, it can be concluded that the proportion of the largest shareholders in real estate enterprises in the sample is usually around 38\%, and the largest proportion of the largest shareholders can reach $80 \%$ and the smallest is $7 \%$. According to Table 2 , it can be 
proved that Chinese real estate listed firms have less managerial ownership, with an average of around $6 \%$, which indicates that the situation of managerial ownership seems to be unimportant. Regarding control variables, the mean value of firm size shows that the average value of total assets is 5.2 billion RMB, and its standard deviation is around 131, which indicates that the total assets among companies fluctuate greatly. The average ROA is 0.02 , implying that the real estate industry has a relatively low ability to obtain net profit. The average fixed asset ratio is at a low level of 3 per cent. The average growth rate of assets representing the companies' ability to grow is nearly $16 \%$.

Insert table (2) around here

\subsection{Correlation analysis}

Table 3 shows the correlation coefficient matrix among all the variables. As for the relationship between dependent variables and independent variables, the board size has a significant positive correlation with TD, STD and LTD, which means that the larger the board size is, the more debt financing the enterprise can get. As for board independence, it only has a significant negative relationship with TD. According to Table 3, when the CEO duality existents in a company, the company can get more debt, especially short-term debt. The ownership concentration is significantly correlated with TD and STD at 1\% significant level, and their Pierce coefficients are 0.18 and 0.162 , respectively. Both state-owned shareholdings and management shareholdings are significantly related with STD and LTD. Second, in terms of the Pearce correlation coefficients between the independent variable and the control variable, the firm size is significantly positively correlated with TD, STD and LTD, which means that the larger the firm size is, the higher the debt ratio is. PROFIT is negatively correlated with TD and LTD. The proportion of fixed assets is negatively correlated with TD and STD, while the growth is negatively correlated with TD, STD and LTD. In terms of the relationship among independent variables, there seems to be a strong negative correlation between board size and board independence, which may indicate that the larger the board size is, the smaller the proportion of independent directors is. In addition, there is also a strong positive correlation between ownership concentration and the proportion of state-owned holding. Additionally, board independence and CEO duality are negatively correlated at a significant level of 5\%. What is more, board independence and ownership concentration are positively correlated at a significant level of 5\%. In relation to the correlation among dependent variables, the correlation 
coefficient between TD and STD is 0.71 , which means that the total debt ratio is highly correlated with short-term debt ratio. However, The Pearce coefficient of TD and LTD is 0.55 , lower than 0.71 . And it is worth noting that there is a significant negative correlation between LTD and STD at the level of 1\%, which indicates that the long-term debt and short-term debt of the real estate industry are mutually exclusive.

\section{Insert table (3) around here}

Table 3 results showed that there is no multicollinearity problem in our sample as the correlation coefficient is below 0.70 .

\subsection{Regression result}

The multiple linear regression analysis results are shown in Table 4. According to Table 4, the $\mathrm{P}$-value of the three groups of models is $1 \%(\mathrm{P}=0.000)$, which indicates that the significance level of the three groups of models is very high, which shows that these three sets of models have statistical significance. In addition, R2 of TD, STD and LTD are $0.498,0.243$ and 0.308 respectively, which indicates that $50 \%, 24 \%$ and $31 \%$ of TD, STD and LTD respectively are explained by the independent variables. Since most studies only use the total debt ratio to represent the capital structure (Wen et al., 2002; Boateng et al., 2017; Butt and Hasan 2009; Ganiyu and Abiodun, 2012), this paper mainly analyzes the regression results based on the total debt ratio. In terms of corporate governance variables, the ownership concentration is significantly positively correlated with the capital structure, the board size has a weak positive correlation with the capital structure, while the state-owned ownership is negatively related to the capital structure, and the rest of independent variables are not statistically correlated with the capital structure. In terms of the control variables, capital structure is only affected by firm size and profitability.

\section{Insert table (4) around here}

In terms of corporate governance variables, firstly, according to Table 4, the ownership concentration is significantly positively relevant to the total debt ratio at the level of $1 \%$, and hypothesis 4 is accepted, which is same as the expectation of this paper, and indicates their positive relationship. Further, the ownership concentration is significantly positively correlated with the short-term debt ratio, but has nothing to do with long-term debt ratio. Based on the 
correlation coefficient shown in Table 4 for every unit increase in ownership concentration, TD and STD will increase by 0.207 and 0.247 units, respectively. These results are consistent with agency theory and Mande et al. (2012). Their empirical evidence indicates that the higher the ownership concentration of Chinese listed real estate enterprises is, the more inclined they are to debt financing, especially short-term debt financing, which also implies that the severe expropriation effect of the major shareholders in the real estate industry. In addition, GranadoPeiró and López-Gracia (2017) believe that when the ownership concentration is below 34\%, that is, when ownership concentration is low, the ownership concentration and the capital structure are often inversely correlated, because there is no large shareholders to fully perform the supervision function to management. However, when ownership concentration exceeds this ratio, the two are positively correlated. According to the descriptive statistics, the average shareholding ratio of major shareholders in the real estate industry is about $38.3 \%$, more than $34 \%$. It can be proved that the ownership concentration of the real estate industry is high, and major shareholders have fully performed their supervision functions.

State ownership has a statistically negative correlation with the capital structure at the level of $1 \%$. Specifically, the state-owned has a significant positive correlation with the short-term debt ratio, but has no correlation with the long-term debt ratio. These research results support hypothesis 5 and reveal their negative relationship. This means that for Chinese real estate companies, the higher the state ownership, the less likely they are to use debt financing. This research opinion is contrary to Li et al. (2009), who believes that the debt ratio is positively affected by state ownership in Chinese enterprises, which indicates that the relationship between ownership concentration and capital structure of Chinese real estate industry is different from that of overall Chinese industry. The reason for this phenomenon may be that due to the special economic and cultural status of the real estate industry in China. This aggravates the problems of congenital incomplete property rights of state and acquired

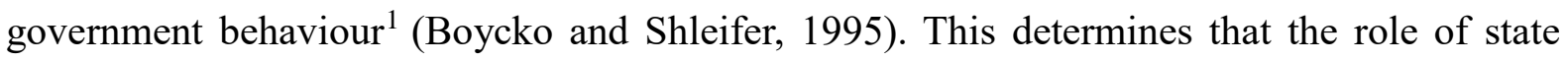
shareholders as a supervisor is not fully played, contributing to managers' internal control deficiencies and moral hazards, which may affect the efficiency of corporate governance, leading to the management to reduce the debt ratio to avoid risks.

Board size is weakly positively associated with the capital structure, to be more specific, the

\footnotetext{
${ }^{1}$ Attaches great importance to the political purposes related to social development, and ignore the enterprise profit purposes (Boycko and Shleifer, 1995).
} 
board size is positively correlated with the long-term debt ratio at the level of $1 \%$, but not statistically correlated with short-term debt ratio, these results accept hypothesis 1 . The results suggest that in Chinese real estate industry, the larger the board is, the management are more likely to finance through debt. This empirical evidence is consistent with the research results of Wen et al. (2002) and agency theory, who believe that large boards are more stable because of superior oversight by regulators. Thus boards tend to seek higher leverage to increase corporate value.

Both board independence and CEO duality have no statistical significance on total debt ratio, and only have a weak impact on long-term debt ratio respectively, which rejects our hypothesis 2 and hypothesis 3 . Our interpretation for this result might be due to the social characteristics of China, such as collectivist culture and socialist political connections (Chen et al., 2011). The board of directors in China is often destroyed by its composition, and independent directors seem powerless (Dahya et al., 2003; Wang, 2008), which may result in the inability of independent directors to influence capital structure decisions. The research result of the correlation between CEO duality and capital structure is in line with Bopkin and Arko (2009), which may be related to the fact that CEO duality is not universal in Chinese real estate industry based on the descriptive statistical results.

The management ownership has no impact on total debt ratio, rejecting hypothesis 6 . As shown in Table 2, the proportion of the management shareholding of listed companies of real estate is generally low, which makes management have no greater incentives to increase the value of the financing decision through the adjustment of capital structure, this may be the reason for that the management ownership has nothing to do with capital structure.

Referring to the relationship between control variables and dependent variable(s), the capital structure is greatly impacted by the firm size and profitability, which is consistent with the expectation of this paper, while asset tangibility and firm growth have nothing to do with capital structure, which rejects the expectation of this paper. Specifically, firm size is positively correlated with total debt ratio and short-term debt ratio, indicating that in the real estate industry, the larger the company size is, the greater the possibility of debt financing is, especially short-term debt financing. Fama and French (2002) also agree with these results. In addition, firm profitability has a significant negative correlation with total debt ratio. Further, the profitability has no correlation with short-term debt ratio, but has a negative correlation 
with long-term debt ratio, which means that the more profitable a company is, the less debt it needs. This conclusion is accepted by the trade-off theory, which holds that the companies with high profitability usually have sufficient cash flow, thus they tend to require less debt financing (Sharma and Kumar, 2011). Asset tangibility has nothing to do with the total debt ratio. According to descriptive statistics, the Chinese real estate industry relies more on short-term debt than long-term debt, and fixed assets are not suitable for short-term debt financing (Dasilas and Papasyriopoulos 2015). Therefore, the tangible assets have little impact on the total debt ratio. Growth has nothing to do with TD, LTD and STD, these research results are consistent with Huang (2006), Psillaki and Daskalakis (2009), whom all believe that there is no statistical correlation between growth and capital structure.

All in all, the results of the STD model and TD model are generally consistent, which is related to the large proportion of short-term debt in the capital structure of the real estate industry. What is more, it is obviously can be seen that the influence of ownership structure on capital structure is greater than that of board structure.

\subsection{Robustness test}

In this part, in order to confirm the stability of the regression results, a robustness analysis has carried out. The robustness analysis in this paper is to carry out a multiple regression again by replacing some variables.

$$
\begin{aligned}
& \text { Capital Structure }\left(T D_{i, t} ; S T D_{i, t} ; L T D_{i, t}\right) \\
& =\alpha_{0}+\beta_{1} B O D_{i, t}+\beta_{2} I D R_{i, t}+\beta_{3} D U A_{i, t}+\beta_{4} O C^{1}{ }_{i, t}+\beta_{5} S T A T E_{i, t} \\
& +\beta_{6} \text { MGT }_{i, t}+\beta_{7} \text { SIZE }_{i, t}^{1}+\beta_{8} \text { PROFIT }_{i, t}^{1}+\beta_{9} \text { TANG }_{i, t}+\beta_{10} \text { GROWT H }_{i, t}^{1} \\
& +\varepsilon_{i, t}
\end{aligned}
$$

Independent variables

$O C_{i, t}^{1} \quad=$ Shareholding ratio of the TOP 5 shareholders of firm $i$ in year $t$ $=\frac{\text { shareholding of the TOP } 5 \text { shareholders }}{\text { The total number of shares }}$

Control variables

$\operatorname{SIZE}_{i, t}^{1} \quad=$ Firm size of firm $i$ in year $t=$ The natural logarithm of the total sales

PROFIT $_{i, t}^{l} \quad=$ profitability of firm $i$ in year $t=\frac{E B I T}{\text { total equity }}$

GROWTH $_{i, t}{ }=$ The growth rate of total sales of firm $i$ in year $t$ 
Specifically: (1) as for ownership concentration, this paper changes the shareholding ratio of the largest shareholder (OC) to the top five shareholders $\left(\mathrm{OC}^{1}\right)$, which avoids the extreme sample problem caused by only selecting the largest shareholder. (2) in relation to the firm size, the logarithm of total assets (SIZE) is replaced by the logarithm of sales (SIZE ${ }^{1}$ ). Kang and Ausloos, (2017) also used the logarithm of sales to measure the firm size; (3) regarding the firm profitability, return on assets (PROFIT) is replaced by return on equity (PROFIT ${ }^{1}$ ), and in the studies of Qi et al. (2000), Dasilas and Papasyriopoulos (2015), the robustness tests are also carried out in this way; (4) in terms of firm growth, the growth rate of total assets (GROWTH) is replaced by the growth rate of sales $\left(\mathrm{GROWTH}^{1}\right)$, the same method is also found in the research of Abor (2007), at the same time, this approach is also to keep in line with the firm size variables. We tested for multicollinearity and our results showed no multicollinearity among the variables. We also run Hausman test and fixed effect models are adopted for TD and STD, and the random effect model is adopted for LTD (results are available if needed).

The regression results of the robustness test are shown in Table 5. According to Table 5, it can be seen that the research results of this paper are relatively stable on the whole, except that the board size changes from a weak correlation with the capital structure to an unrelated relationship. As shown in Table 5, the board size is weakly positively correlated with the capital structure at the level of $10 \%$, and the correlation disappears in the robustness test. Besides, ownership concentration and state-owned ownership still have positive and negative effects on capital structure, respectively, which is consistent with the initial regression model. Additionally, the irrelevant relationships between CEO duality, management ownership and capital structure are strengthened. Specifically, the weak correlation between CEO duality and long-term debt ratio becomes insignificant, and the weakly negative correlation between management shareholding ratio and short term debt ratio becomes irrelevant. As for the control variables, the relationship between firm size and capital structure, and the relationship between profitability and capital structure are consistent with the regression results of the original model. Furthermore, the unrelated correlation between assets tangibility and capital structure is strengthened, and its weak correlation with long-term liabilities becomes irrelevant.

To sum up, the results of the robustness test are consistent with those of the initial regression analysis on the whole, which indicates that the regression analysis results of this paper are reliable. 


\section{Conclusion}

This study investigates how corporate governance mechanisms may improve capital structure management. Based on a sample of 119 Chinese real estate listed firms from 2014 to 2018, our research results suggest that firstly, ownership concentration is positively correlated with capital structure, which supports agency theory. This implies that ownership concentration can alleviate the agency problem by increasing the debt, thus reducing the agency cost, because the major shareholders can fully perform their supervisory functions (Liu et al., 2011). Secondly, the negative relationship between state-owned shareholding and capital structure rejects agency theory. This indicates that the lack of supervisory function of state-owned shareholders in Chinese real estate industry. The research results that the state-owned shareholding ratio is negatively correlated with the capital structure, which is contrary to the prior studies (Xu and Wang, 1999; Tian, 2001; Zou and Xiao, 2006), proves the uniqueness of Chinese real estate industry and indicates that the state-owned share shareholders in this industry do not fully play their supervisory role.

Our study contributes to both corporate governance and capital structure literature in many ways. Firstly, we contribute to agency theory by providing further evidence that agency cost plays an important role in both capital structure and corporate governance decisions related to financial policy (Granado-Peir and López-Gracia, 2017). Specifically, managers may use debt financing a useful governance mechanism in decreasing the conflict of interests between the agent and principal (Jensen, 1986). In other words, debt can serve as a substitute mechanism to attenuate the agency costs of free cash flow available to managers (Jensen, 1986; Hussainey, Aljifri, 2012). This makes agency problems less severe and have only a weak influence on the capital structure decisions. This is mainly because large shareholders manage these internal control systems and are responsible for supporting operating and strategic management decisions of firms, in addition, to engage in an effective financing policy. Second, while there are many studies focused solely on corporate structure (Brailsford et al., 2002) or corporate governance (Abor and Biekpe, 2005; Ali et al., 2014; Ganiyu and Abiodun, 2012), few studies covered the combinations of the two (Butt, and Hasan, 2009). Our paper considers the influences of both board structure (board size, board independence and CEO duality) and ownership structure (ownership concentration, management ownership and state ownership) on capital structure. Third, the results of the few studies that covered the relationship between corporate governance and capital structure are inconsistent. This study accentuates the possible 
influence of the corporate governance mechanism on the capital structure decisions in Chinese context. It extends the existing research on the influence of corporate governance mechanisms. This may help financial information users to evaluate the influence of such factors in refining capital structure decisions. Our results likewise suggest that there is a need to support policymakers in China to ensure that companies apply effective corporate governance mechanisms. This application should be suitable for the Chinese environment while integrating international corporate governance codes. It is likely that the successful application of corporate governance code will develop efficiency, effectiveness and governance of stock market and firm decisions by improving the regulatory and enforcement frameworks. Fourth, our paper examines the above relationship in China because of its unique nature of corporate governance. Finally, we add new evidence from the real estate industry. The development of the real estate industry is very important to promote Chinese economic development and economic restructuring (Chen et al., 2009). Additionally, it is worth noting that Chinese governments rely more on real estate industry income (Xu et al., 2016), which also implies that the state ownership in the real estate industry may affect corporate governance and may act as remedies for controlling agency conflicts.

From the perspective of improving corporate governance, this paper has practical significance for corporate capital structure decision-making, especially for the real estate industry. Firstly, as for the board structure, this study implies that the independent directors in China may be undermined, which makes it impossible for independent directors to influence capital structure decisions. Therefore, the real estate industry should attach importance to the power of independent directors. In the aspect of ownership structure, this paper proves that the greater the degree of ownership concentration, the more information will be transmitted to investors, indicating that the large shareholders of the enterprise can fulfil their supervisory role, thus enabling the company to get more debt financing. As for the negative correlation between the proportion of state-owned shares and the capital structure, it shows that the supervision role of the state as shareholders has not been fully realized, and the state-owned shareholders should adjust their role.

Our study is not free from research limitations that might lead to future research. Firstly, our study in line with some prior studies in relation to some missing corporate governance variables. This includes CEO compensation (Berger et al., 1997; Abor and Biekpe, 2005), CEO tenure 
(Wen et al., 2002; Abor, 2007) and management expertise (Abor and Biekpe, 2005; Ganiyu and Abiodun, 2012). These variables might have impact on capital structure decision-making. Future research can include such variables in their models. Secondly, we only focused on Chinese real estate industry, further research can expand to include other sectors and other countries. Thirdly, according to agency theory (Jensen and Mecking, 1976), debt can alleviate agency problems, which to some extent indicates that capital structure may also affect corporate governance, which is also a future research direction. 


\section{References}

Abor, J. (2007). Corporate governance and financing decisions of Ghanaian listed firms. Corporate Governance: The international journal of business in society, 7(1), pp.83-92.

Abor, J. and Biekpe, N. (2005). September. Does corporate governance affect the capital structure decisions of Ghanaian SMEs. In Biennial Conference of the Economic Society of South Africa, Durban, South Africa, September.

Abor, J. and Biekpe, N. (2007). Corporate governance, ownership structure and performance of SMEs in Ghana: implications for financing opportunities. Corporate Governance: The international journal of business in society, 7(3), pp.288-300.

Adel, C., Hussain, M., Mohamed, E. and Basuony, M. (2019), "Is corporate governance relevant to the quality of corporate social responsibility disclosure in large European companies?", International Journal of Accounting \& Information Management, Vol. 27 No. 2, pp. 301-332.

Agyei, A. and Owusu, A.R. (2014). The effect of ownership structure and corporate governance on capital structure of Ghanaian listed manufacturing companies. International Journal of Academic Research in Accounting, Finance and Management Sciences, 4(1), pp.109-118.

AlHares, A. (2020), "Corporate governance and cost of capital in OECD countries", International Journal of Accounting \& Information Management, Vol. 28 No. 1, pp. 1-21.

AlHares, A., Elamer, A., Alshbili, I. and Moustafa, M. (2020), "Board structure and corporate R\&D intensity: evidence from Forbes global 2000", International Journal of Accounting \& Information Management, Vol. ahead-of-print No. ahead-of-print. https://doi.org/10.1108/IJAIM-11-2019-0127

Ali, N., Nasir, N.M. and Satti, S.L. (2014). The Effect of Corporate Governance on Capital Structure Decisions-A Case of Saudi Arabian Banking Sector. Acta Universitatis Danubius: Oeconomica, 10(2).

Allam, A., Ghattas, N., Kotb, A., \& Eldaly, M. K. (2017). Audit Tendering in the UK: A Review of Stakeholders' Views. International Journal of Auditing, 21(1), 11-23.

Alshbili, I., \& Elamer, A. A. (2019). The influence of institutional context on corporate social responsibility disclosure: a case of a developing country. Journal of Sustainable Finance \& Investment, 1-25. https://doi.org/10.1080/20430795.2019.1677440

Arping, S., \& Sautner, Z. (2010). Corporate governance and leverage: Evidence from a natural experiment. Finance Research Letters, 7(2), 127-134.

Bebchuk, L.A. and Weisbach, M.S., 2010. The state of corporate governance research. The review of financial studies, 23(3), pp.939-961.

Berger, P.G., Ofek, E. and Yermack, D.L. (1997). Managerial entrenchment and capital structure decisions. The journal of finance, 52(4), pp.1411-1438.

Bhabra, H.S., Liu, T. and Tirtiroglu, D. (2008). Capital structure choice in a nascent market: Evidence from listed firms in China. Financial Management, 37(2), pp.341-364.

Boateng, A. and Huang, W. (2017). Multiple large shareholders, excess leverage and tunneling: Evidence from an emerging market. Corporate Governance: An International Review, 25(1), pp.58-74.

Boateng, A., Cai, H., Borgia, D., Bi, X. G., \& Ngwu, F. N. (2017). The influence of internal corporate governance mechanisms on capital structure decisions of Chinese listed firms. Review of Accounting and Finance, 16(4), 444-461.

Boateng, A., Cai, H., Borgia, D., Gang Bi, X. and Ngwu, F.N. (2017). The influence of internal corporate governance mechanisms on capital structure decisions of Chinese listed firms. Review of Accounting and Finance, 16(4), pp.444-461.

Bodaghi, A., \& Ahmadpour, A. (2010). The effect of corporate governance and ownership structure on capital structure of Iranian listed companies. In 7th International Conference on Enterprise Systems, Accounting and Logistics (7th ICESAL 2010) (pp. 28-29).

Bokpin, G.A. and Arko, A.C. (2009). Ownership structure, corporate governance and capital structure 
decisions of firms: Empirical evidence from Ghana. Studies in Economics and Finance, 26(4), pp.246-256.

Boycko, M. and Shleifer, A. (1995). Next steps in privatization: Six major challenges. In Library of Congress Cataloging- in- Publication Data, Washington, DC (p. 87).

Brailsford, T.J., Oliver, B.R. and Pua, S.L. (2002). On the relation between ownership structure and capital structure. Accounting \& Finance, 42(1), pp.1-26.

Butt, S.A. and Hasan, A. (2009). Impact of ownership structure and corporate governance on capital structure of Pakistani listed companies. International Journal of Business \& Management, 4(2).

Chang, C., Chen, X. and Liao, G. (2014). What are the reliably important determinants of capital structure in China?. Pacific-Basin Finance Journal, 30, pp.87-113.

Chen, J., Ezzamel, M. and Cai, Z. (2011). Managerial power theory, tournament theory, and executive pay in China. Journal of corporate finance, 17(4), pp.1176-1199.

Chen, J., Guo, F. and Zhu, A. (2009). Housing wealth, financial wealth and consumption in China. China \& World Economy, 17(3), pp.57-74.

China Security Market and Accounting Research. (2019). [online] Available at: http://en.gtafe.com/ [Accessed 14 Aug. 2019].

Ching, H.Y., Novazzi, A. and Gerab, F. (2011). Relationship between working capital management and profitability in Brazilian listed companies. Journal of global business and economics, 3(1), pp.74-86.

Chow, Y. P., Muhammad, J., Bany-Ariffin, A. N., \& Cheng, F. F. (2018). Macroeconomic uncertainty, corporate governance and corporate capital structure. International Journal of Managerial Finance, 14(3), 301-321.

Council, A.C.G. (2007). Corporate governance principles and recommendations.

Dahya, J., Karbhari, Y., Xiao, J.Z. and Yang, M. (2003). The usefulness of the supervisory board report in China. Corporate governance: An international review, 11(4), pp.308-321.

Danso, A., Lartey, T., Fosu, S., Owusu-Agyei, S. and Uddin, M. (2019), "Leverage and firm investment: the role of information asymmetry and growth", International Journal of Accounting \& Information Management, Vol. 27 No. 1, pp. 56-73.

Danso, A., Lartey, T., Fosu, S., Owusu-Agyei, S., \& Uddin, M. (2019). Leverage and firm investment: the role of information asymmetry and growth. International Journal of Accounting and Information Management, 27(1), 56-73.

Dasilas, A. and Papasyriopoulos, N. (2015). Corporate governance, credit ratings and the capital structure of Greek SME and large listed firms. Small Business Economics, 45(1), pp.215-244.

Daskalakis, N. and Psillaki, M. (2008). Do country or firm factors explain capital structure? Evidence from SMEs in France and Greece. Applied financial economics, 18(2), pp.87-97.

Data.stats.gov.cn. (2019). Chinese National Bureau of Statistics. [online] Available at: http://data.stats.gov.cn/easyquery.htm?cn=C01 [Accessed 24 Jul. 2019].

Elamer, A. A., Ntim, C. G., \& Abdou, H. A. (2020a). Islamic Governance, National Governance, and Bank Risk Management and Disclosure in MENA Countries. Business \& Society, 59(5), 914 955.

ELdaly, M. K. A. (2012). Responsibility of Egyptian banks' auditors for going concern assumption in light of Egyptian Central Bank Law No. 88/2003. International Journal of Economics and Accounting, 3(3/4), 344.

Eldaly, M. K., \& Abdel-Kader, M. (2018). How to regain public trust in audit firms? The case of the Financial Reporting Council. Accounting Research Journal, 31(3), 343-359.

Elmagrhi, M. H., Ntim, C. G., Elamer, A. A., \& Zhang, Q. (2018). A study of environmental policies and regulations, governance structures, and environmental performance: the role of female directors. Business Strategy and the Environment, 28(1), 206-220.

Faccio, M., Lang, L.H. and Young, L. (2010). Pyramiding vs leverage in corporate groups: international evidence. Journal of International Business Studies, 41(1), pp.88-104. 
Fama, E.F. and French, K.R. (2002). Testing trade-off and pecking order predictions about dividends and debt. The Review of Financial Studies, 15(1), pp.1-33.

Fama, E.F. and Jensen, M.C. (1983). Separation of ownership and control. The Journal of Law and Economics, 26(2), pp.301-325.

Fama, E.F. and Miller, M.H. (1972). The theory of finance. Holt Rinehart \& Winston.

Feinerman, J.V. (2017). New hope for corporate governance in China?. In Law and the Market Economy in China (pp. 97-119). Routledge.

Fosberg, R.H. (2004). Agency problems and debt financing: leadership structure effects. Corporate Governance: The international journal of business in society, 4(1), pp.31-38.

Ganiyu, Y.O. and Abiodun, B.Y. (2012). The impact of corporate governance on capital structure decision of Nigerian firms. Research Journal in Organizational Psychology \& Educational Studies, 1(2), pp.121-128.

Gerged, A. M., \& Agwili, A. (2020). How corporate governance affect firm value and profitability? Evidence from Saudi financial and non-financial listed firms. International Journal of Business Governance and Ethics, 14(2), 144-165.

Gerged, A. M., Cowton, C. J., \& Beddewela, E. S. (2018). Towards Sustainable Development in the Arab Middle East and North Africa Region: A Longitudinal Analysis of Environmental Disclosure in Corporate Annual Reports. Business Strategy and the Environment, 27(4), 572587.

Gerged, A., \& Elheddad, M. (2020). How can national governance affect education quality in Western Europe? International Journal of Sustainability in Higher Education. https://doi.org/10.1108/IJSHE-10-2019-0314

Ghosh, C., Giambona, E., Harding, J. P., \& Sirmans, C. F. (2011). How entrenchment, incentives and governance influence REIT capital structure. The Journal of Real Estate Finance and Economics, 43(1-2), 39-72.

Granado-Peiró, N. and López-Gracia, J. (2017). Corporate governance and capital structure: a Spanish study. European Management Review, 14(1), pp.33-45.

Guo, L., Smallman, C. and Radford, J. (2013). A critique of corporate governance in China. International Journal of Law and Management, 55(4), pp.257-272.

Haque, F., Arun, T.G. and Kirkpatrick, C. (2011). Corporate governance and capital structure in developing countries: a case study of Bangladesh. Applied Economics, 43(6), pp.673-681.

Hassan, A., Adhikariparajuli, M., Fletcher, M., \& Elamer, A. (2019). Integrated reporting in UK higher education institutions. Sustainability Accounting, Management and Policy Journal, 10(5), 844876.

Hassan, A., Elamer, A. A., Fletcher, M., \& Sobhan, N. (2020). Voluntary assurance of sustainability reporting: evidence from an emerging economy. Accounting Research Journal. https://doi.org/10.1108/ARJ-10-2018-0169

Huang, G. (2006). The determinants of capital structure: Evidence from China. China economic review, 17(1), pp.14-36.

Huang, W. (2019), "Ownership, tax and intercorporate loans in China", International Journal of Accounting \& Information Management, Vol. 27 No. 1, pp. 111-129.

Huang, W., Boateng, A. and Newman, A. (2016). Capital structure of Chinese listed SMEs: an agency theory perspective. Small Business Economics, 47(2), pp.535-550.

Hussainey, K., \& Aljifri, K. (2012). Corporate governance mechanisms and capital structure in UAE. Journal of Applied Accounting Research, 13(2), 145-160.

Jensen, M.C. (1986). Agency costs of free cash flow, corporate finance, and takeovers. The American economic review, 76(2), pp.323-329.

Jensen, M.C. (1993). The modern industrial revolution, exit, and the failure of internal control systems. the Journal of Finance, 48(3), pp.831-880.

Jensen, M.C. and Meckling, W.H. (1976). Theory of the firm: Managerial behavior, agency costs and 
ownership structure. Journal of financial economics, 3(4), pp.305-360.

Jiraporn, P., Kim, J.C., Kim, Y.S. and Kitsabunnarat, P. (2012). Capital structure and corporate governance quality: Evidence from the Institutional Shareholder Services (ISS). International Review of Economics \& Finance, 22(1), pp.208-221.

Kang, M. and Ausloos, M. (2017). An Inverse Problem Study: Credit Risk Ratings as a Determinant of Corporate Governance and Capital Structure in Emerging Markets: Evidence from Chinese Listed Companies. Economies, 5(4), p.47.

Kim, H. J., Kotb, A., \& Eldaly, M. K. (2016). The use of generalized audit software by Egyptian external auditors: The effect of audit software features. Journal of Applied Accounting Research, 17(4), 456-478.

Kim, W.S. and Sorensen, E.H. (1986). Evidence on the impact of the agency costs of debt on corporate debt policy. Journal of Financial and quantitative analysis, 21(2), pp.131-144.

Korteweg, A. (2010). The net benefits to leverage. The Journal of Finance, 65(6), pp.2137-2170.

Kumar, J. (2005). Corporate governance mechanisms and firm financing in India. In Proceedings of the International Conference on Emerging Securities Market: Challenges and Prospects, The Securities Exchange Board of India (SEBI) and the ICFAI University, Mumbai.

Li, K., Yue, H. and Zhao, L. (2009). Ownership, institutions, and capital structure: Evidence from China. Journal of comparative economics, 37(3), pp.471-490.

Li, M., \& Song, L. (2018). Corporate governance, accounting information environment and investment-cash flow sensitivity. International Journal of Accounting and Information Management, 26(4), 492-507.

Lin, C., Ma, Y., Malatesta, P. and Xuan, Y. (2011). Ownership structure and the cost of corporate borrowing. Journal of Financial Economics, 100(1), pp.1-23.

Lin, J.Y., Cai, F. and Li, Z. (1998). Competition, policy burdens, and state-owned enterprise reform. The American Economic Review, 88(2), pp.422-427.

Lin, Z.J., Liu, M. and Zhang, X. (2006). The Development of Corporate Governance in China. AsiaPacific Management Accounting Journal, 1(1), pp.29-47.

Liu, Q., Tian, G. and Wang, X. (2011). The effect of ownership structure on leverage decision: new evidence from Chinese listed firms. Journal of the Asia Pacific Economy, 16(2), pp.254-276.

Long, Y. e., \& Huang, X. (2020). Do equity incentives for the managements have impact on stockpricing efficiency? Evidence from China. International Journal of Accounting and Information Management.

Mac an Bhaird, C. (2010). Resourcing small and medium sized enterprises: A financial growth life cycle approach. Springer Science \& Business Media.

Mande, V., Park, Y.K. and Son, M. (2012). Equity or debt financing: does good corporate governance matter?. Corporate Governance: An International Review, 20(2), pp.195-211.

Mateev, M., Poutziouris, P. and Ivanov, K. (2013). On the determinants of SME capital structure in Central and Eastern Europe: A dynamic panel analysis. Research in International Business and Finance, 27(1), pp.28-51.

Mehran, H. (1992). Executive incentive plans, corporate control, and capital structure. Journal of Financial and Quantitative analysis, 27(4), pp.539-560.

Mirza, S.S., Jebran, K., Yan, Y. and Iqbal, A. (2017). Financing behavior of firms in tranquil and crisis period: Evidence from China. Cogent Economics \& Finance, 5(1), p.1339770.

Morri, G. and Cristanziani, F. (2009). What determines the capital structure of real estate companies? An analysis of the EPRA/NAREIT Europe Index. Journal of Property Investment \& Finance, 27(4), pp.318-372.

Muttakin, M. B., Mihret, D., Lemma, T. T., \& Khan, A. (2020). Integrated reporting, financial reporting quality and cost of debt. International Journal of Accounting and Information Management. https://doi.org/10.1108/IJAIM-10-2019-0124

Neves, M. E., Serrasqueiro, Z., Dias, A., \& Hermano, C. (2020). Capital structure decisions in a period 
of economic intervention: Empirical evidence of Portuguese companies with panel data. International Journal of Accounting and Information Management. https://doi.org/10.1108/IJAIM-08-2019-0094

Ortiz-Molina, H. \& Penas, M.F. (2008). Lending to small businesses: the role of loan maturity in addressing information problems, Small Business Economics, 30(4), pp. 361-383.

Palacín-Sánchez, M.J., Ramírez-Herrera, L.M. and Di Pietro, F. (2013). Capital structure of SMEs in Spanish regions. Small Business Economics, 41(2), pp.503-519.

Psillaki, M. and Daskalakis, N. (2009). Are the determinants of capital structure country or firm specific?. Small business economics, 33(3), pp.319-333.

Qi, D., Wu, W. and Zhang, H. (2000). Shareholding structure and corporate performance of partially privatized firms: Evidence from listed Chinese companies. Pacific-Basin Finance Journal, 8(5), pp.587-610.

Qian, Y. and Wu, J. (2003). China's transition to a market economy. How far across the river, pp.3163.

Rajagopalan, N. and Zhang, Y. (2008). Corporate governance reforms in China and India: Challenges and opportunities. Business Horizons, 51(1), pp.55-64.

Rehman, M.A., Rehman, R.U. and Raoof, A. (2010). Does corporate governance lead to a change in the capital structure. American Journal of Social and Management Sciences, 1(2), pp.191-195.

Ruan, W., Tian, G. and Ma, S. (2011). Managerial ownership, capital structure and firm value: Evidence from China's civilian-run firms. Australasian Accounting, Business and Finance Journal, 5(3), pp.73-92.

Saad, N.M. (2010). Corporate governance compliance and the effects to capital structure in Malaysia. International Journal of Economics and Finance, 2(1), pp.105-114.

Santos, M.S., Moreira, A.C. and Vieira, E.S. (2014). Ownership concentration, contestability, family firms, and capital structure. Journal of Management \& Governance, 18(4), pp.1063-1107.

Schipani, C.A. and Liu, J. (2002). Corporate governance in China: then and now. Colum. Bus. L. Rev., p.1.

Sharma, A.K. and Kumar, S. (2011). Effect of working capital management on firm profitability: Empirical evidence from India. Global Business Review, 12(1), pp.159-173.

Shleifer, A. and Vishny, R.W. (1997). A survey of corporate governance. The journal of finance, 52(2), pp.737-783.

Short, H., Keasey, K. and Duxbury, D. (2002). Capital structure, management ownership and large external shareholders: a UK analysis. International Journal of the economics of Business, 9(3), pp.375-399.

Sogorb-Mira, F. (2005). How SME uniqueness affects capital structure: Evidence from a 1994-1998 Spanish data panel. Small business economics, 25(5), pp.447-457.

$\mathrm{Su}, \mathrm{K}$. (2015). The inner structure of pyramid and capital structure: Evidence from China. Economics: The Open-Access, Open-Assessment E-Journal, 9(2015-14), pp.1-30.

Tian, L. (2001), March. State shareholding and the value of China's firms. In EFA 2001 Barcelona Meetings.

Ullah, M., Muttakin, M. and Khan, A. (2019), "Corporate governance and corporate social responsibility disclosures in insurance companies", International Journal of Accounting \& Information Management, Vol. 27 No. 2, pp. 284-300.

Uwuigbe, U. (2014). Corporate governance and capital structure: evidence from listed firms in Nigeria Stock Exchange. The Journal of Accounting and Management, 4(1).

Vakilifard, H.R., Gerayli, M.S., Yanesari, A.M. and Ma'atoofi, A.R. (2011). Effect of corporate governance on capital structure: Case of the Iranian listed firms. European Journal of Economics, Finance and Administrative Sciences, 35, pp.165-172.

Wang, J. (2008). The Strange Role of Independent Directors in a Two-Tier Board Structure in China's Listed Companies. In Changing Corporate Governance Practices in China and Japan (pp. 185- 
205). Palgrave Macmillan, London.

Wang, X., Manry, D. and Rosa, G. (2019). Ownership structure, economic fluctuation, and capital structure: Evidence from China. International Journal of Finance \& Economics, 24(2), pp.841854.

Wen, Y., Rwegasira, K. and Bilderbeek, J. (2002). Corporate governance and capital structure decisions of the Chinese listed firms. Corporate Governance: An International Review, 10(2), pp.75-83.

$\mathrm{Xu}$, L., McIver, R.P., Shan, Y.G. and Wang, X. (2016). Governance and performance in China's real estate sector. Managerial finance, 42(6), pp.585-603.

$\mathrm{Xu}, \mathrm{X}$. and Wang, Y. (1999). Ownership structure and corporate governance in Chinese stock companies. China economic review, 10(1), pp.75-98.

Yu, M., \& Wang, Y. (2018). Firm-specific corporate governance and analysts' earnings forecast characteristics: Evidence from Asian stock markets. International Journal of Accounting and Information Management, 26(3), 335-361.

Yuan, R., Xiao, J.Z., Milonas, N. and Zou, J.H. (2009). The role of financial institutions in the corporate governance of listed Chinese companies. British Journal of Management, 20(4), pp.562-580.

Zou, H. and Adams, M.B. (2008). Debt capacity, cost of debt, and corporate insurance. Journal of Financial and Quantitative Analysis, 43(2), pp.433-466.

Zou, H. and Xiao, J.Z. (2006). The financing behaviour of listed Chinese firms. The British Accounting Review, 38(3), pp. 239-258. 
Tables

Table (1) Summary of variables and measurement (Original test)

\begin{tabular}{|c|c|c|}
\hline Variables & Acronym & Definitions and coding. \\
\hline $\begin{array}{l}\text { Dependent } \\
\text { Variable: } \\
\text { Corporate } \\
\text { structure }\end{array}$ & $\begin{array}{l}\text { TD } \\
\text { STD } \\
\text { LTD }\end{array}$ & $\begin{array}{l}\text { Total debt ratio=total debt/total asset. (Haque et al., 2011). } \\
\text { Short-term debt ratio= short-term debt/total asset. (Dasilas and } \\
\text { Papasyriopoulos, 2015). } \\
\text { Long-term debt ratio =long-term debt/total asset. ( Dasilas and } \\
\text { Papasyriopoulos, 2015). }\end{array}$ \\
\hline $\begin{array}{l}\text { Independent } \\
\text { Variables: } \\
\text { Corporate } \\
\text { governance }\end{array}$ & $\begin{array}{l}\text { DUA } \\
\text { OC } \\
\text { STATE }\end{array}$ & $\begin{array}{l}\text { Board size = the natural logarithm of the total number of board } \\
\text { directors (Kang and Ausloos, 2017) } \\
\text { The proportion of independent directors=the number of } \\
\text { independent directors/the total number of board directors } \\
\text { (Boateng et al., 2017) } \\
\text { CEO duality =1 if CEO is chairman, otherwise, 0. (Saad, 2010; } \\
\text { Uwuigbe, 2014) } \\
\text { Shareholding ratio of the largest shareholder =shareholding of } \\
\text { the largest shareholder/the total number of shares. (Boateng et } \\
\text { al., 2017) } \\
\text { Shareholding ratio of the state-owned shareholders } \\
=\text { shareholding of the state-owned shareholders/The total number } \\
\text { of shares. Liu et al., (2011) } \\
\text { Shareholding ratio of the TOP } 5 \text { shareholders=shareholding of } \\
\text { the TOP } 5 \text { shareholders/The total number of shares } \\
\text { Shareholding ratio of management }=\text { shareholding of } \\
\text { management/the total number of shares. (Jiraporn et al., 2012). }\end{array}$ \\
\hline $\begin{array}{l}\text { Control } \\
\text { variables: }\end{array}$ & $\begin{array}{l}\text { SIZE } \\
\text { PROFIT } \\
\text { TANG } \\
\text { GROWTH }\end{array}$ & $\begin{array}{l}\text { Firm size }=\text { The natural logarithm of the total asset. (Huang et } \\
\text { al., 2016). } \\
\text { Firm profitability=EBIT/total assets. (Bhabra et al., 2008). } \\
\text { Asset tangibility=fixed assets/total assets. (Santos et al., 2014) } \\
\text { Growth ability = The growth rate of total assets. (Chang et al., } \\
\text { 2014) }\end{array}$ \\
\hline
\end{tabular}

Note: All the data collected from the China Securities Market and Accounting Research Database (CSMAR). 
Table (2) Descriptive statistics

\begin{tabular}{|c|c|c|c|c|c|c|c|}
\hline \multicolumn{2}{|c|}{ Definition } & No.obs & Mean & StdDev & Median & Min & Max \\
\hline TD & $\begin{array}{l}\text { Total debt/total } \\
\text { asset }\end{array}$ & 595 & 0.646 & 0.181 & 0.671 & 0.088 & 0.984 \\
\hline STD & $\begin{array}{l}\text { Short-term } \\
\text { debt/total asset }\end{array}$ & 595 & 0.429 & 0.153 & 0.437 & 0.027 & 0.819 \\
\hline LTD & $\begin{array}{l}\text { Long-term } \\
\text { debt/total asset }\end{array}$ & 595 & 0.217 & 0.129 & 0.219 & 0 & 0.556 \\
\hline Board size & $\begin{array}{l}\text { Number of board } \\
\text { members }\end{array}$ & 595 & 8.642 & 1.776 & 9 & 4 & 18 \\
\hline $\begin{array}{l}\text { Independent } \\
\text { directors }\end{array}$ & $\begin{array}{l}\text { Proportion of } \\
\text { independent } \\
\text { directors }\end{array}$ & 595 & 0.381 & 0.058 & 0.364 & 0.3 & 0.667 \\
\hline CEO duality & $\begin{array}{l}\text { One person as } \\
\text { CEO and } \\
\text { chairman }\end{array}$ & 595 & 0.175 & 0.380 & 0 & 0 & 1 \\
\hline $\begin{array}{l}\text { Ownership } \\
\text { concentration }\end{array}$ & $\begin{array}{l}\text { Share proportion } \\
\text { of the largest } \\
\text { shareholders }\end{array}$ & 595 & 0.383 & 0.160 & 0.37 & 0.071 & 0.806 \\
\hline $\begin{array}{l}\text { State } \\
\text { shareholdings }\end{array}$ & $\begin{array}{l}\text { Proportion of } \\
\text { state-owned } \\
\text { shares }\end{array}$ & 595 & 0.031 & 0.107 & 0 & 0 & 0.761 \\
\hline $\begin{array}{l}\text { Management } \\
\text { shareholdings }\end{array}$ & $\begin{array}{l}\text { Proportion of } \\
\text { management } \\
\text { shares }\end{array}$ & 595 & 0.017 & 0.056 & 0 & 0 & 0.368 \\
\hline Firm size & $\begin{array}{l}\text { Total asset (in } \\
\text { billions, } ¥ \text { ) }\end{array}$ & 595 & 52.642 & 131.014 & 14.329 & 0.198 & 1528.579 \\
\hline Profitability & EBIT/total assets & 595 & 0.021 & 0.048 & 0.019 & $\begin{array}{c}- \\
0.533\end{array}$ & 0.193 \\
\hline Tangibility & $\begin{array}{l}\text { Fixed assets/total } \\
\text { assets }\end{array}$ & 595 & 0.030 & 0.055 & 0.014 & 0 & 0.575 \\
\hline Growth & $\begin{array}{l}\text { Growth rate of } \\
\text { total assets }\end{array}$ & 595 & 0.156 & 0.283 & 0.129 & $\begin{array}{c}- \\
0.451\end{array}$ & 3.391 \\
\hline
\end{tabular}


Table (3) Correlation Matrix

\begin{tabular}{|c|c|c|c|c|c|c|c|c|c|c|c|c|c|}
\hline & TD & STD & LTD & BOD & IDR & DUA & $\mathrm{OC}$ & STATE & MGT & SIZE & PROFIT & TANG & GROWTH \\
\hline TD & 1 & & & & & & & & & & & & \\
\hline STD & $0.711 * * *$ & 1 & & & & & & & & & & & \\
\hline LTD & $0.552 * * *$ & $-0.194 * * *$ & 1 & & & & & & & & & & \\
\hline BOD & $0.148 * * *$ & $0.068 *$ & $0.125 * * *$ & 1 & & & & & & & & & \\
\hline IDR & -0.05 & $-0.077 *$ & 0.021 & $-0.573 * * *$ & 1 & & & & & & & & \\
\hline DUA & $-0.101 * *$ & $-0.154 * * *$ & 0.042 & 0.046 & $-0.085^{* *}$ & 1 & & & & & & & \\
\hline OC & $0.180 * * *$ & $0.162 * * *$ & 0.059 & -0.001 & $0.090 * *$ & $0.074 *$ & 1 & & & & & & \\
\hline STATE & 0.008 & $0.069 *$ & $-0.071 *$ & $0.068 *$ & 0.051 & -0.048 & $0.165^{* * *}$ & 1 & & & & & \\
\hline MGT & 0.021 & $0.151 * * *$ & $-0.150 * * *$ & -0.046 & -0.012 & $-0.073 *$ & $-0.084 * *$ & -0.054 & 1 & & & & \\
\hline SIZE & $0.657 * * *$ & $0.446 * * *$ & $0.387 * * *$ & $0.195 * * *$ & 0.03 & $-0.071 *$ & $0.183^{* * *}$ & $0.083 * *$ & 0.013 & 1 & & & \\
\hline PROFIT & $-0.142 * * *$ & 0.000 & $-0.198 * * *$ & $0.118 * * *$ & $-0.088 * *$ & $0.103 * *$ & $0.098 * *$ & $0.073^{*}$ & $0.116 * * *$ & $0.115 * * *$ & 1 & & \\
\hline TANG & $-0.179 * * *$ & $-0.225 * * *$ & 0.018 & 0.011 & -0.006 & 0.061 & 0.042 & -0.007 & -0.056 & $-0.268 * * *$ & $-0.093 * *$ & 1 & \\
\hline GROWTH & $0.205 * * *$ & $0.152 * * *$ & $0.106^{* * * *}$ & $0.107 * * *$ & $-0.084 * *$ & $-0.107 * * *$ & 0.02 & 0.004 & 0.042 & $0.234 * * *$ & $0.099 * *$ & $-0.117 * * *$ & 1 \\
\hline
\end{tabular}

Note:

$* * *$ Correlation is significant at 0.01 level (2-tailed); **Correlation is significant at 0.05 level (2-tailed); *Correlation is significant at 0.10 level (2-tailed).

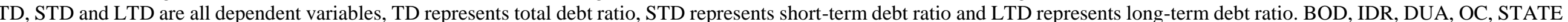

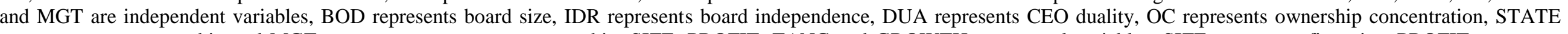

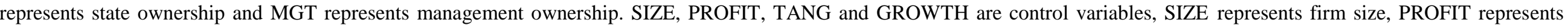
profitability, TANG represents asset tangibility and GROWTH represents growth ability. 


\begin{tabular}{lrrr}
\hline VARIABLES & \multicolumn{2}{l}{ TD } & \multicolumn{1}{l}{ LTD } \\
\hline BOD & $0.175^{*}$ & -0.128 & $0.242^{* * *}$ \\
& $(1.68)$ & $(-1.002)$ & $(2.894)$ \\
IDR & 0.108 & -0.132 & $0.201^{*}$ \\
& $(0.911)$ & $(-0.910)$ & $(1.946)$ \\
DUA & 0.015 & -0.006 & $0.024^{* *}$ \\
& $(1.168)$ & $(-0.398)$ & $(2.062)$ \\
OC & $0.207^{* * *}$ & $0.247^{* * *}$ & -0.019 \\
& $(3.727)$ & $(3.617)$ & $(-0.474)$ \\
STATE & $-0.211^{* * *}$ & $-0.221^{* * *}$ & -0.035 \\
& $(-4.337)$ & $(-3.714)$ & $(-0.803)$ \\
MGT & 0.125 & $0.226^{*}$ & $-0.169^{*}$ \\
& $(1.143)$ & $(1.688)$ & $(-1.809)$ \\
SIZE & $0.131^{* * *}$ & $0.094^{* * *}$ & $0.064^{* * *}$ \\
& $(7.951)$ & $(4.634)$ & 5.951 \\
ROA & $-0.614^{* * *}$ & -0.15 & $-0.492^{* * *}$ \\
& $(-8.230)$ & $(-1.641)$ & $(-6.724)$ \\
TANG & 0.034 & -0.126 & $0.190^{* *}$ \\
GROWTH & $(0.296)$ & $(-0.906)$ & $(1.968)$ \\
& 0.018 & 0.009 & 0.01 \\
Constant & $(1.379)$ & $(0.533)$ & $(0.81)$ \\
& $-0.971^{* * *}$ & $-0.437^{*}$ & $-0.744^{* * *}$ \\
Observations & $(-4.729)$ & $(-1.734)$ & $(-5.289)$ \\
Number of code & 595 & 595 & 595 \\
R-squared & 119 & 119 & 119 \\
F_value & 0.4987 & 0.2483 & 0.3084 \\
Wald chi2 $(10)$ & 16.1 & 5.35 & \\
Prob>F & & & 100.27 \\
Prob>chi2 & 0.000 & 0.000 & \\
\hline Note - tst & & & 0.000 \\
\hline
\end{tabular}

Note: t-statistics in parentheses, figures without parentheses are regression coefficients of every parameter. ${ }^{* * *}$ Significant at $1 \%$ (2-tailed). $* *$ Significant at $5 \%$ (2-tailed). * Significant at $10 \%$ (2-tailed). TD, STD and LTD are all dependent variables, TD represents total debt ratio, STD represents short-term debt ratio and LTD represents long-term debt ratio. BOD, IDR, DUA, OC, STATE and MGT are independent variables, BOD represents board size, IDR represents board independence, DUA represents CEO duality, OC represents ownership concentration, STATE represents state ownership and MGT represents management ownership. SIZE, PROFIT, TANG and GROWTH are control variables, SIZE represents firm size, PROFIT represents profitability, TANG represents asset tangibility and GROWTH represents growth ability. 
Table (5) Robustness test

\begin{tabular}{|c|c|c|c|c|}
\hline VARIABLES & TD & STD & LTD & VIF \\
\hline$\overline{B O D}$ & $\begin{array}{c}0.1760 \\
(1.516)\end{array}$ & $\begin{array}{c}-0.1090 \\
(-0.836)\end{array}$ & $\begin{array}{l}0.268 * * * \\
(3.0160)\end{array}$ & 1.59 \\
\hline IDR & $\begin{array}{l}0.0580 \\
(0.438)\end{array}$ & $\begin{array}{l}-0.1700 \\
(-1.143)\end{array}$ & $\begin{array}{r}0.217^{* *} \\
(1.9790)\end{array}$ & 1.53 \\
\hline DUA & $\begin{array}{r}0.0040 \\
(0.281)\end{array}$ & $\begin{array}{r}-0.0080 \\
(-0.497)\end{array}$ & $\begin{array}{r}0.0140 \\
(1.1840)\end{array}$ & 1.04 \\
\hline $\mathrm{OC}^{1}$ & $\begin{array}{r}0.002 * * * \\
(3.099)\end{array}$ & $\begin{array}{r}0.003 * * * \\
(3.3090)\end{array}$ & $\begin{array}{r}-0.0000 \\
(-0.079)\end{array}$ & 2.21 \\
\hline STATE & $\begin{array}{r}-0.219 * * * \\
(-3.825)\end{array}$ & $\begin{array}{r}-0.242 * * * \\
(-3.765)\end{array}$ & $\begin{array}{r}-0.0350 \\
(-0.749)\end{array}$ & 1.09 \\
\hline MGT & $\begin{array}{r}0.0130 \\
(0.109)\end{array}$ & $\begin{array}{r}0.1420 \\
(1.0480)\end{array}$ & $\begin{array}{r}-0.213^{* *} \\
(-2.154)\end{array}$ & 1.04 \\
\hline $\mathrm{SIZE}^{1}$ & $\begin{array}{r}0.042 * * * \\
(3.075)\end{array}$ & $\begin{array}{r}0.044 * * * \\
(2.8640)\end{array}$ & $\begin{array}{l}0.020 * * \\
(2.0880)\end{array}$ & 1.27 \\
\hline PROFIT $^{1}$ & $\begin{array}{r}-0.009 * * * \\
(-3.405)\end{array}$ & $\begin{array}{l}-0.0040 \\
(-1.219)\end{array}$ & $\begin{array}{r}-0.006^{* *} \\
(-2.439)\end{array}$ & 1.02 \\
\hline TANG & $\begin{array}{r}-0.0730 \\
(-0.603)\end{array}$ & $\begin{array}{l}-0.2130 \\
(-1.576)\end{array}$ & $\begin{array}{r}0.1230 \\
(1.2480)\end{array}$ & 1.06 \\
\hline GROWTH $^{1}$ & $\begin{array}{r}0.0000 \\
(0.2480)\end{array}$ & $\begin{array}{l}-0.0000 \\
(-0.770)\end{array}$ & $\begin{array}{r}0.0000 \\
-1.0340\end{array}$ & 1.05 \\
\hline Constant & $\begin{array}{l}-0.0510 \\
(-0.283)\end{array}$ & $\begin{array}{r}0.0550 \\
(0.2720)\end{array}$ & $\begin{array}{r}-0.312 * * \\
(-2.340)\end{array}$ & \\
\hline $\begin{array}{l}\text { Observations } \\
\text { R-squared }\end{array}$ & $\begin{array}{r}595 \\
0.322\end{array}$ & $\begin{array}{r}595 \\
0.2237\end{array}$ & $\begin{array}{r}595 \\
0.143\end{array}$ & \\
\hline Number of code & 119 & 119 & 119 & \\
\hline F_value & 4.5 & 4.05 & & \\
\hline Wald chi2 (10) & & & 29.99 & \\
\hline $\begin{array}{l}\text { Prob }>F \\
\text { Mean VIF } \\
\text { Prob }>\text { chi2 }\end{array}$ & 0.000 & 0.000 & 0.000 & 1.19 \\
\hline
\end{tabular}

Note: t-statistics in parentheses, figures without parentheses are regression coefficients of every parameter. $* * *$ Significant at $1 \%$ (2-tailed). ** Significant at 5\% (2-tailed). * Significant at 10\% (2-tailed). TD, STD and LTD are all dependent variables, TD represents total debt ratio, STD represents short-term debt ratio and LTD represents long-term debt ratio. BOD, IDR, DUA, OC1, STATE and MGT are independent variables, BOD represents board size, IDR represents board independence, DUA represents CEO duality, OC1 represents ownership concentration, STATE represents state ownership and MGT represents management ownership. SIZE1, PROFIT1, TANG and GROWTH1 are control variables, SIZE1 represents firm size, PROFIT1 represents profitability, TANG represents asset tangibility and GROWTH1 represents growth ability. 